\title{
THE RELATIONSHIP BETWEEN LEAN APPROXIMATION AND ENVIRONMENT
}

\author{
Ozgur Demirtas, Inonu University, Turkey \\ Neslihan Derin, Inonu University, Turkey
}

\begin{abstract}
Many businesses have come to realize that environmentally-aware applications have gained a competitive edge, even at increased competition environments. These businesses can make several investments to protect the environment. Contrary to our expectations, regarding environmental protection, there is no need for huge investments on issues such as waste recycling, reduction of emissions, and energy conservation. Businesses can become environmentally friendly by lean approach applications that are becoming widespread gradually. The idea of reducing any waste, the basis of the lean approach, can contribute to the protection of the environment by providing a safer use of scarce resources in the environment and by leaving a minimal amount of waste to the environment. Therefore, the purpose of this study is to examine the usefulness and effects of lean multi-dimensional applications for managing environmentally sensitive businesses. This paper employs an analysis of the literature that examines the relationship between lean thinking and green management. A thorough analysis has indicated that businesses that combine lean approaches and green practices have a better chance to reach positive outcomes, and attain sustainable strategic competitive advantage in their organizational environment.
\end{abstract}

Keywords: environment, lean approach, management, sustainable competitive advantage. 


\section{Introduction}

Industrial Revolution could be considered as a milestone pinpointing a considerable turning point in the evolution of the human species. While industrial activities are vital to the progress and development of mankind, they inevitably lead to undesirable impacts on the environment (Dhingra, R., Kress, R. \& Upreti, G., 2014). We could cite the following developments as some 'undesirable impacts': global warming, grow of hole in the ozone layer, the beginning of drought along with the decrease of water resources, almost a halt in fish migration with the increasing world temperature, glaciers' beginning to melt quickly in the northern hemisphere (Gok, M.Ş. \& ArıCI, T 2016).

The industrial activity should be efficient and effective enough to fulfill our needs. At the same time, those activities should not violate the ecosystems' carrying capacity (Dhingra, R., Kress, R. \& Upreti, G., 2014), which reminds us of 'environmental efficiency'. Environmental efficiency which is achieved through the reduction of environmental impact by using more efficient materials and less unrenewable natural resources in manufacturing is associated with, to a great extent, process and operational decisions which are categorized as pollution prevention (Rothenberg, S., Pil, F. K., \& Maxwell, J., 2001). Companies are advised to implement more 'environmental-friendly' initiative in order to stay competitive and economically sustainable. Manufacturers will need to change their traditional production techniques with a more sustainable approach to minimize the number of manufacturing steps using advanced and alternative methods (Cheung, W. M., Leong, J. T., \& Vichare, P., 2017). One of these 'advanced and alternative methods' is lean approach. Lean approach is one of the most influential manufacturing paradigm of recent times that can be considered as a multi-dimensional approach encompassing a wide variety of management practices, including just-in-time, quality management, work teams, etc., in an integrated system that produces finished products at the pace of the customer demand with little or no waste. Lean thinking has raised the idea that batches should always be as small as possible, in order to achieve onepiece flow with batches sizes of one (Rubio, S., \& Corominas, A., 2008).

Lean initiatives are primarily focused on maximizing productivity by increasing output per unit of input, conserving resources, reducing waste, minimizing costs; green initiatives, however, are concerned with protecting the environment as well (Dhingra, R., Kress, R. \& Upreti, G., 2014). There has been much anecdotal evidence suggesting that a lean approach can help make a case for environmental impact reduction to businesses. An integrated lean and green approach has revealed results in (i) a reduction in waste production and (ii) a reduction in environmental impact (Pampanelli, A. B., Found, P., \& Bernardes, A. M., 2014).

\section{Lean Approach}

First developed in the Japanese automotive industry, Lean Manufacturing now is seen as the primary management technique for industrial firms. The lean approach was a concept referring to the new management style used by the Japanese automotive industry which uses less of everything compared to mass production (Abdi, F., Shavarini, S. K., \& Hoseini, S. M. S., 2006). Lean production aims to protect value within an organization with overall work and so maximizing efficiency through the reduction of waste. Although all these systems set about in the production industry, the notion of the "production process" can easily be implemented to any other set of processes, even those that do not manufacture physical products. As a result, lean production has been much effective as a method of thinking in numerous industries beyond its automotive roots (Roosen, T. J., \& Pons, D. J., 2013).

Lean production thinking or "Lean" is an application that helps businesses detect and eliminate waste through continuous improvement, by controlling their lean tools (Verrier B., Rose B., Caillaud E. Remita H., 
2014). Lean thinking is a fully new way of thinking about the roles of business, functions, and careers to channel the flow of value from notion to movement, order to consignment, and unprocessed material into the hands of the client in order to accomplish a step forward. It symbolizes a new notion that triggers the overall 'value stream' for products dramatically in the way of excellence (Carvalho, H., Govindan, K., Azevedo, S. G., \& Cruz-Machado, V., 2017).

The main objective of the lean approach is to eliminate waste in all processes of the business including customer relations, product design, supplier networks, and firm management. Lean approach, producing quality products in an economical way and meeting customer demand most effectively, aims to use fewer people, less inventory, less product development time, less space. The lean approach allows value to be isolated from "waste" by changing the center of interest of management and achieve abundance by focusing on work that will impact the product and the production of resources, instead of fixed assets technologies, organizations (Gerger, A., \& Demir, B., 2010).

Basic lean principles and objectives can be listed as follows (Emiliani, M. L., \& Stec, D. J, 2005):

- $\quad$ Continuous Improvement: to carry out the activities which will lead to better management in market conditions changing day to day. This fact, labeled "kaizen" as Japanese, means change and transition to a better state.

- Respect for Persons: Human beings (e.g associates, customers, suppliers, investors, and society) are precious because they are special

- $\quad$ Creating Value for Customers: To focus on value creation activities that reflects customer desires.

- $\quad$ Eliminating Waste: To remove only the activities that lead to an increase in cost but do not add any value to the customer who makes the final use of the product.

A series of tools were developed to help map and as a result, eliminate three fields. These were "Muda", also known as the seven wastes, "Muri" the overloading of people or equipment, and "Mura" the varied or unsteady manufacture. The taxonomy put forward to define the seven primary wastes (Muda), plus the eighth waste of underutilization of people added later in development are as follows: Transportation, Inventory, Motion, Waiting, Over-processing, Overproduction, Defects, and underutilization (Roosen, T. J., \& Pons, D. J., 2013).

The purpose of eliminating those types of waste is to increase efficiency, reduce costs, improve customer reply time, and subscribe to improved quality, bigger profitability, and an improved public image. The business should, however, accomplish efficiency not only by performing practices such as Lean, but also by decreasing their environmental effect (Verrier, B., Rose, B., Caillaud, E., \& Remita, H., 2014).

Identifying clean environmental practices per se requires the reduction of waste at its genesis. Waste is not produced by a plant but it is the result of individual processes within the production. Therefore, in order to achieve focused management of environmental waste, plants need production engineers who not only know what the waste is but also where it is being generated. This is the gist of the problem because people involved in production processes generally do not have accurate information about this problem. In addition, even when production plants are controlled and improved by lean methods, some waste may still be not visible to the lean methods, then that waste will not be included in the continuous improvement cycles which could be in turn means that effective use of lean tools in identifying and embedding the environmental issues (Roosen, T. J., \& Pons, D. J., 2013). 
Examples of such "lean tools" are:

- Value Stream Mapping,

- 5S, Kanban (pull systems),

- Poka-Yoke, Heijunka,

- Six Sigma,

- Kanbans,

- First In-First Out (FIFO),

- Takt (from Taktzeit meaning cycle time),

- Just In Time (JIT),

- Total Preventative Maintenance-TPM,

- Pull, flow, low setup, controlled processes, productive maintenance,

- $\quad$ Single Minute Dye Exchange (SMDE).

To use such tools in lean approaches target zero wastage or zero defects leading to the prevention and reduction of environmental harm. This goal is accomplished by the influential use of sources from reduced waste, reduced quantity of material lost to scrap, and less energy or time used up in producing the required output (Pampanelli, A. B., Found, P., \& Bernardes, A. M., 2014; Roosen, T. J., \& Pons, D. J., 2013; Yang M.G., Hong P., Modi S.B.. 2011; Kurdve, M., Zackrisson, M., Wiktorsson, M., \& Harlin, U., 2014; Sajan M.P., Shalij P.R., Ramesh A., Biju Augustine P., 2017).

\section{Relationships between Environment and Lean Approach}

For their survival and profitability, institutions have begun to understand the need to regain the appropriate image toward sincere, dignified, humane, friendly structure from soulless, careless, impersonal, immoral structure since the beginning of the $20^{\text {th }}$ century. Therefore, institutions have tried to embrace a new image by acting more friendly to the environment and society throughout the $20^{\text {th }}$ century (Munshi, D., \& Kurian, P., 2005).

The spreading of green practices contributes to a set of advantages such as cost reduction through a more efficient use of resources, business sustainability, protecting the environment, and better firm image. These advantages show that the implementation of green practices can positively impact the business's performance. They also mean that a business has attached in some proactive environmental attitude, doings that are designed to reduce pollution and to develop the economic performance of the business (Carvalho, H., Govindan, K., Azevedo, S. G., \& Cruz-Machado, V., 2017).

Several studies on this subject also confirm the arguments mentioned above. For example, according to the study of Innovest Strategic Value Advisors, an international social research company, they have emphasized that more than $\% 43$ of share prices of the business which sells wood and paper products, is more careful about damaging the environment. Businesses in the petrol and gas industry also have been found that they have surpassed their competitors with a 12 percent share price above according to the last three years' values (Phillips J, 2007).

The manufacturer can simultaneously adopt and combine Lean and Green strategies in order to create an environmental stance that is a driver for reduced costs and risks, increased revenue, and improved brand image. Phrases such as "Lean is Green" have become increasingly mainstream. Steve Hope, general manager of Toyota Motor Europe, stated that the whole company should be "green, clean and lean". Lean not only serves as a catalyst but also is synergistic with the Green strategy. This means that Lean is beneficial for Green practices and the implementation of Green practices, in turn, has a positive influence on existing business practices [20]. Lean techniques do assist in the minimization of waste and pollution and promote the use of environmental management tools (Carvalho, H., Govindan, K., Azevedo, S. G., \& Cruz-Machado, V., 2017).

The main purpose of the Lean idea may not be the environmental contribution. Because, it aims to reduce waste and improve value, and it is also customer-focused (e.g. high quality, low cost, short lead times) (Fercoq, A., Lamouri, S., \& Carbone, V., 2016; Khodeir, L. M., \& Othman, R., 2016). However, the research shows that enterprises that have 
succeeded in reducing wastage in internal processes by using lean manufacturing methods also reveal the best environmental management practices (Agarwal, A., \& Sharma, M. K., 2016).

There are some researches that directly explore the relationships between Lean Production and environment or green management. Beginning from the 1990s, some authors started to investigate this subject. For the first time, through observational case studies, some of these authors emphasized a relationship between these systems. In addition, at the beginning of the 2000s a more relevant debate on the topic started. Indeed, research about the integration of Lean agile systems and environmental sustainability of the supply chain seems to have become more prolific as many papers demonstrate (Chiarini, A., 2014).

King and Lenox (2001) examined to find empirical evidence of the link between lean production practices and environmental performance. They conducted some analyses of the environmental performance of 17,499 U.S. manufacturing establishments during the time period 1991-1996. They found strong evidence that lean production, as measured by ISO 9000, is complementary to waste reduction and pollution reduction. Another study that was being done by Chiriani examined some observation for some European companies (five companies), which are belonging in the manufacturing of some spare parts of motorcycles depending on the idea of the Lean and Environment Management Approach. For this study, the authors observed and measured some processes that are associated with Lean tools (e.g. Value Stream Mapping-VSM, 5S, cellular manufacturing, Single Minute Exchange of Die-SMED and Total Productive MaintenanceTPM). The authors have found some interesting innovative results for the effects of Lean Management Idea on some environmental outcomes. One of these findings reveals that VSM can be used as a tool for exploring the impacts of production processes. The other of the findings for $5 \mathrm{~S}$ is found to be a useful tool for managing the waste system. In addition, Cellular manufacturing has found to be a positive influence on reducing electricity consumption. In addition, total productive maintenance has been found to be an effect on reducing oil leakage, dust emissions or some chemical outcomes. But, the authors didn't find any significant related to the effect of Single Minute Exchange of Die (Chiarini, A., 2014).

Another study in the literature has emphasized that lean leads to green (Dhingra, R., Kress, R., \& Upreti, G. 2014). According to the authors, integrating the idea of lean and green thinking is a positive way for attaining innovative solutions, but in their core concepts, there are some differences between them. They are coming from different field of study fields, but we can combine the ideas of lean and green concepts as in the idea of green productivity, ecoefficiency, eco-effectiveness, and sustainable business practices

Besides, in their study Cheung et al. (2017) have reached some novel ideas. For example, they emphasized a cross-functional mapping approach that links the idea of Lean Thinking and Life Cycle Analysis-LCA. The main idea for this linkage is depending on the re-evaluation of carbon footprint for an existing plastic product. The main idea for this research is minimizing the negative environmental influence of plastic injections with the aim of the integration of lean thinking and life cycle analysis. The authors also emphasized that the overall influence for this integration is approximately $40 \%$ for climate change, human toxicity, photochemical oxidant formation, acidification, and eco-toxicity.

In another study, Pampanelli et al. (2014) emphasized a novel idea that is the "Lean and Green Model" indicating the idea of integrating environmental sustainability and lean thinking, which is stemming from the Kaizen approach. The main idea for this model is to apply lean thinking idea for manufacturing environments where most of the production depends on mass and energy flows. In their model, the authors applied their model at an international engineering 
corporation and limited their study for cell level, which is the first stream level of a manufacturing business that supports the principles of lean thinking. Their findings indicate that the Lean and Green Model can reduce resource usage approximately by $30 \%$ to $50 \%$ on average. The authors also emphasized that this model has the potential for reducing the costs of mass and energy flows in a cell by $5 \%$ to $10 \%$.

As can be seen from the literature of Lean Production, with the idea of lean thinking most of the firms can have a chance to reach effective and efficient solutions. Because, this idea emphasizes the connection between Lean and Green, and it has an important influence on the efficient energy usage of some resources and the reduction of some waste and pollution. In order to get the Leanness, applying the idea of green practices has a catalyser effect for attaining green goals. Thus, the literature of integrating lean and green can use some innovative ideas that are describing Lean and Green applications as a synergistic joint of environment and firms' operations. Because, as indicated by Dües et al. (2013), lean is a beneficial way for green practices. With the aim of lean thinking, organizations have a better chance to reach some innovative green outcomes.

\section{Discussion}

The literature findings confirm the relationship between Lean Thinking and Green Management. Specifically, we have observed that many of the firms which are applying the practices of Lean Thinking and Management concepts in their organizations have positive outcomes for attaining innovative green outcomes. In addition to attaining profits and values in the market, the organizations also have a chance to gain a positive image (e.g. socially responsible firms for their shareholders) in their corporate environment.

Agarwal \& Sharma (2016) indicate that firms applying the Lean Management Idea in their organizations are called as proactive firms. Because, the authors think that these firms integrate lean and green management concept, and reach positive outcomes for waste management, and optimal resource usage from the environment.

In the earlier times, business leaders looked upon compliance with environmental regulations as an extra cost and an accounting burden for their organizations. But, today they have begun to increasingly adopt prevention-oriented environmental practices on an ongoing basis with the environmental performance beginning to occupy an important place in product development, along with functional performance (Dhingra, R., Kress, R., \& Upreti, G. 2014).

Implementations of lean thinking as input for lean production have an important influence on the environment (e.g. resource usage, waste management and so on). Thus, as in the idea of lean and environmentally friendly, the organizations should focus on energy consumption and material residue, which are the inputs and outputs of a transformation system. In this context, it can be stated that the adoption of lean production practices improves the organization's environmental performance (Jabbour, C. J. C., de Sousa Jabbour, A. B. L., Govindan, K., Teixeira, A. A., \& de Souza Freitas, W. R., 2013).

The lean approach has a chance to provide competitive advantages for both the business and the country, by revealing the problems of the systems' processes and showing more efficient ways of working (Zhu, O., Sarkis J., 2004). At the same time, a lean approach is an important example of business system innovations which improves the organizational and individual productivity (Alpenberg, J., \& Scarbrough, D. P., 2016; Ncube, L. B., 2010). Because, lean thinking is not the only a set of tools, but it is also a managerial approach for improving processes based on a complex system of interrelated socio-technical practices (Fercoq, A., Lamouri, S., \& Carbone, V., 2016).

From the above analysis, we can assert that all shareholders will be consistently more satisfied when an organization applies the 
lean approach. With the aim of this idea, shareholders should receive more positive outcomes. For example, customers can attain higher service qualities or products that can reach optimal processes that emphasize green solutions, or the organizations can reach optimal prices or timing. In addition, some employees should reach career growths, or suppliers will be happy to be a member of this system. Besides, the organizations can obtain a positive image that emphasizes the "Socially Responsible Organization". Most important of all, the other stakeholder, "Environment", will be happy to reach more green and liveable attributions with the contributions of lean approach applications.

The lean approach has contributed to environmental and financial improvements through "Green Supply Chain Practices" (Zhu, O., Sarkis J., 2004). As a result of all this, the positive image of the corporations in the eyes of their shareholders can attain higher places in their organizational environment. That's why; scholars propose that the adoption of lean management practices has an important influence on the environmental performance of manufacturing establishments. In other words, the literature wants to assert that lean is green (King, A. A., \& Lenox, M. J., 2001). 


\section{References}

Abdi, F., Shavarini, S. K., \& Hoseini, S. M. S. (2006). Glean lean: how to use lean approach in service industries?. Journal of services Research, 6, 191.

Alpenberg, J., \& Scarbrough, D. P. (2016). Exploring communication practices in lean production. Journal of Business Research, 69(11), 4959-4963.

Agarwal, A., \& Sharma, M. K. (2016). Lean management-a step towards sustainable green supply chain. Competitiveness Review, 26(3), 311-331.

Carvalho, H., Govindan, K., Azevedo, S. G., \& Cruz-Machado, V. (2017). Modelling green and lean supply chains: An eco-efficiency perspective. Resources, Conservation and Recycling, 120, 75-87.

Cheung, W. M., Leong, J. T., \& Vichare, P. (2017). Incorporating lean thinking and life cycle assessment to reduce environmental impacts of plastic injection moulded products. Journal of Cleaner Production, 167, 759-775.

Chiarini, A. (2014). Sustainable manufacturing-greening processes using specific Lean Production tools: an empirical observation from European motorcycle component manufacturers. Journal of Cleaner Production, 85, 226-233.

Dhingra, R., Kress, R., \& Upreti, G. (2014). Does lean mean green?. Journal of Cleaner Production, 85, 17.

Dües, C. M., Tan, K. H., \& Lim, M. (2013). Green as the new Lean: how to use Lean practices as a catalyst to greening your supply chain. Journal of cleaner production, 40, 93-100.

Emiliani, M. L., \& Stec, D. J. (2005). Leaders lost in transformation. Leadership \& Organization Development Journal, 26(5), 370-387.

Fercoq, A., Lamouri, S., \& Carbone, V. (2016). Lean/Green integration focused on waste reduction techniques. Journal of Cleaner production, 137, 567-578.

Gerger, A., \& Demir, B. (2010). Otomotiv Servis Hizmetlerinde Yalın Altı Sigma Kullanımı Ile Servis Müşteri Memnuniyet Oranının Arttırılmasına Yönelik Bir Örnek. Taşıt Teknolojileri Elektronik Dergisi, 2(1), 33-47.

Gok, M.Ş. \& Arıcı, T. (2016). Yalın üretim sistemleri ve çevresel yönetimde yenilikçi yaklaşım: Teknolojik yönelim, Turkish Studies, 11(21), 113-124.

Jabbour, C. J. C., de Sousa Jabbour, A. B. L., Govindan, K., Teixeira, A. A., \& de Souza Freitas, W. R. (2013). Environmental management and operational performance in automotive companies in Brazil: the role of human resource management and lean manufacturing. Journal of Cleaner Production, 47, 129-140.

Khodeir, L. M., \& Othman, R. (2016). Examining the interaction between lean and sustainability principles in the management process of AEC industry. Ain Shams Engineering Journal.

King, A. A., \& Lenox, M. J. (2001). Lean and green? An empirical examination of the relationship between lean production and environmental performance. Production and operations management, 10(3), 244-256.

Kurdve, M., Zackrisson, M., Wiktorsson, M., \& Harlin, U. (2014). Lean and green integration into production system models-experiences from Swedish industry. Journal of Cleaner Production, 85, 180-190.

Munshi, D., \& Kurian, P. (2005). Imperializing spin cycles: A postcolonial look at public relations, greenwashing, and the separation of publics. Public Relations Review, 31(4), 513-520.

Ncube, L. B. (2010). A simulation of lean manufacturing: The lean lemonade tycoon 2. Simulation \& Gaming, 41(4), 568-586.

Pampanelli, A. B., Found, P., \& Bernardes, A. M. (2014). A Lean \& Green Model for a production cell. Journal of cleaner production, $85,19-30$.

Phillips J, (2007), Orijinal düşünme sanatı (Çeviri: Şule Gülmen), Prestij Yayınları, İstanbul.

Rothenberg, S., Pil, F. K., \& Maxwell, J. (2001). Lean, green, and the quest for superior environmental performance. Production and operations management, 10(3), 228-243.

Rubio, S., \& Corominas, A. (2008). Optimal manufacturing-remanufacturing policies in a lean production environment. Computers \& Industrial Engineering, 55(1), 234-242.

Roosen, T. J., \& Pons, D. J. (2013). Environmentally lean production: the development and incorporation of an environmental impact index into value stream mapping. Journal of Industrial Engineering, 2013.

Sajan M.P., Shalij P.R., Ramesh A., Biju Augustine P., (2017). Lean manufacturing practices in Indian manufacturing SMEs and their effect on sustainability performance, Journal of Manufacturing Technology Management, 28(6), 772-793. 
Verrier B., Rose B., Caillaud E. Remita H., (2014), Combining organizational performance with sustainable development issues: The Lean and Green project benchmarking repository, Journal of Cleaner Production, 85, 83-93.

Verrier, B., Rose, B., Caillaud, E., \& Remita, H. (2014). Combining organizational performance with sustainable development issues: the Lean and Green project benchmarking repository. Journal of Cleaner Production, 85, 83-93.

Yang M.G., Hong P., Modi S.B. (2011), Impact of lean manufacturing and environmental management on business performance: An empirical study of manufacturing firms, Int. J. Production Economics 129, 251-261.

Zhu, O., Sarkis J. (2004). Relationships between operational practices and performance among early adopters of green supply chain management practices in Chinese manufacturing enterprises, Journal of Operational Management, 22(3), 265-289. 
